\title{
PENGARUH KUALITAS PELAYANAN DAN KETEPATAN PENGIRIMAN TERHADAP KEPUASAN PELANGGAN DALAM MENGGUNAKAN JASA PENGIRIMAN BARANG NINJA EXPRESS DI MASA PANDEMI COVID-19
}

\author{
Saefur Rohman ${ }^{1}$, Fino Wahyudi Abdul ${ }^{2}$ \\ Fakultas Ilmu Sosial dan Manajemen STIAMI \\ Email : $\underline{\text { saefurrohmanmu@gmail.com }}{ }^{1}, \underline{\text { finowahyudi71@gmail.com }}{ }^{2}$
}

\begin{tabular}{|c|c|}
\hline ARTICLE INFO & ABSTRACT \\
\hline $\begin{array}{l}\text { Article History } \\
\text { Received } 13 \text { Oktober } 2020 \\
\text { Revised } 27 \text { Oktober } 2020 \\
\text { Accepted } 10 \text { November } 2020\end{array}$ & $\begin{array}{l}\text { The Effect of Service Quality and Delivery Accuracy on Customer Satisfaction } \\
\text { in Using Ninja Express Freight Forwarding Services during the Covid-19 } \\
\text { Pandemic, Saefur Rohman, NPM: CF116112019, This study aims to determine } \\
\text { how much influence Service Quality and Delivery Accuracy have on customer } \\
\text { satisfaction. The sample used in this study consisted of } 60 \text { respondents } \\
\text { obtained through nonprobability sampling techniques. The method used was } \\
\text { accidental sampling. The dependent variable in this study was Customer } \\
\text { Satisfaction and the independent variables were Service Quality and Delivery } \\
\text { Accuracy. The results of this study indicate that Service Quality and Delivery } \\
\text { Accuracy simultaneously have an effect on Customer Satisfaction. This can be } \\
\text { seen from the results of the f test which shows a significance value of } 0.000 \\
<0.05 \text { and Fcount value of } 21.709>\text { Ftable value of 3.16. This shows that H3 is } \\
\text { accepted. }\end{array}$ \\
\hline
\end{tabular}

\section{PENDAHULUAN}

\section{Latar belakang penelitian}

Perkembangan teknologi di Indonesia saat ini semakin berkembang dengan pesat, terutama yang berkaitan dengan transportasi. Transportasi adalah sarana penunjang penting dalam membantu masyarakat yang memiliki mobilitas sebagai aktifitasnya sehari-hari. Transportasi dapat membantu aktivitas masyarakat seperti perekonomian, pengiriman barang atau jasa, angkutan penumpang, dan sebagainya. Semakin banyaknya transportasi maka akan semakin banyak membantu masyarakat dalam perekonomian.

Di Negara Indonesia terutama di Kota Jakarta saat ini transportasi sudah termasuk salah satu kebutuhan bagi masyarakat. Sehingga peran jasa transportasipun semakin hari semakin dibutuhkan, baik untuk mobilitas masyarakat serta transportasi untuk pengiriman barang ke seluruh wilayah Indonesia.

Dalam hal ini transportasi pengiriman barang berbasis online sangat membantu masyarakat dalam mobilitas pergerakan barang. Mengenai pengiriman barang yang selalu meningkat karena semakin banyaknya pembelanjaan online baik dalam bentuk paket, dokumen, atau parsel sehingga membutuhkan penyedia transportasi pengiriman barang yang efektif dan efisien. Transportasi pengiriman barang berbasis online mendapatkan peluang lebih untuk ber-inovasi menyediakan jasa pengiriman yang selalu membuat masyarakat puas setiap menggunakan jasanya.

Ninja Express saat ini hadir sebagai perusahaan penyedia jasa transportasi pengiriman barang berbasis online, Ninja Express sendiri melayani pengiriman barang hingga keseluruh wilayah Indonesia, Bukan hanya itu pihak Ninja Express sendiri menyediakan layanan penjemputan barang dan mengantarkanya.

Walapun terbilang baru akan tetapi Ninja Express sudah melakukan inovasi dengan melakukan pelanyanan kepada masyarakat melalui kerja sama dengan beberapa Toko Online di Indonesia dan membuat masyarakat dapat dengan mudah melakukan pembelanjaan online, dengan bergabungnya sistem Ninja Express dengan Toko Online secara sadar pihak penyedia jasa pengiriman barang berbasis online ini bersaing dengan banyak kompetitor dengan menunjukan kemampuan masing-masing alam penyedia jasa pengiriman barang. 


\section{Identifikasi masalah}

Berdasarkan latar belakang yang telah penulis kemukakan diatas, maka terdapat beberapa pokok permasalahan yang akan penulis rumuskan adalah sebagai berikut :

a. Seberapa besar pengaruh kualitas pelayanan terhadap kepuasan pelanggan Ninja Express ?

b. Seberapa besar pengaruh ketepatan pengiriman terhadap kepuasan pelanggan Ninja Express ?

\section{Maksud dan tujuan penelitian}

Adapun tujuan dari penelitian ini adalah sebagai berikut :

a. Untuk mengetahui seberapa besar pengaruh Kualitas Pelayanan (X1) terhadap Kepuasan Pelanggan (Y) pada layanan Ninja Express.

b. Untuk mengetahui seberapa besar pengaruh Ketepatan Pengirirman (X2) terhadap Kepuasan Pelanggan (Y) pada layanan Ninja Express.

c. Untuk mengetahui seberapa besar pengaruh Kualitas Pelayanan (X1) dan Ketepatan Pengiriman (X2) terhadap Kepuasan Pelanggan (Y) pada layanan Ninja Express.

\section{KAJIAN LITERATUR}

\section{Logistik}

Logistik berasal dari bahasa Yunani kuno yaitu "Logistikos" yang berarti "terdidik atau terpandai" dalam memeperkirakan atau berhitung. Logistik merupakan seni dan ilmu mengatur dan mengontrol arus barang, energi, informasi, dan sumberdaya lainnya, seperti produk, jasa, dan manusia, dari sumber produksi ke pasar dengan tujuan mengoptimalkan penggunaan modal.

\section{Pengertian manajemen logistik}

The Council of Logistic Management (1998) mendefinisikan Manajemen Logistik merupakan bagian dari proses Supply Chain yang berfungsi untuk merencanakan, melaksanakan dan mengendalikan keefisienan dan keefektifan aliran dan penyimpanan barang, pelayanan dan informasi terkait dari titik permulaan (point of origin) hingga titik konsumsi (point of consumption) dalam tujuannya untuk memenuhi kebutuhan para pelanggan.

\section{Transportasi}

Menurut Andriansyah (2015:19) sistem manajemen transportasi (transportation management system) adalah rangkaian sistem atau pengelolaan terhadap moda transportasi oleh suatu kelompok atau golongan.Karena begitu pentingnya transportasi bagi kehidupan manusia, maka perlu dilakukan pengelolaan atau manajemen transportasi yang baik. Pada umunya, manajemen transportasi menghadapi tiga tugas utama:

a. Menyusun rencana dan program untuk mencapai tujuan dan misi organisasi secara keseluruhan.

b. Meningkatkan produktivitas dan kinerja perusahaan.

c. Mengoperasikan angkutan secara garis besar.

\section{Distribusi}

Distribusi adalah suatu penyampaian barang atau jasa dari produsen ke konsumen dan para pemakai, sewaktu dan dimana barang atau jasa tersebut diperlukan.

\section{Loyalitas}

Loyalitas pelanggan memiliki peran penting dalam sebuah perusahaan, mempertahankan mereka berarti meningkatkan kinerja dan mempertahankan kelangsungan hidup perusahaan. Hal ini menjadi alasan utama suatu perusahaan untuk menarik dan mempertahankan mereka.

\section{Covid-19}

Pada Desember 2019, kasus pneumonia misterius pertama kali dilaporkan di Wuhan, Provinsi Hubei. Sumber penularan kasus ini masih belum diketahui pasti, tetapi kasus pertama dikaitkan dengan pasar ikan di Wuhan. Tanggal 18 Desember hingga 29 Desember 2019, terdapat lima pasien yang dirawat dengan Acute Respiratory Distress Syndrome (ARDS). Sejak 31 Desember 2019 hingga 3 Januari 2020 kasus ini meningkat pesat, ditandai dengan dilaporkanya 44 kasus. Tidak sampai satu bulan, penyakit ini telah menyebardi berbagai provinsi lain di China, Thailand, Jepang, dan Korea Selatan.

Awalnya, penyakit ini dinamakan sementara sebagai 2019 novel coronavirus (2019-nCoV), kemudian WHO mengumumkan nama baru pada 11 Februari 2020 yaitu Coronavirus Disease (Covid-19). 
Virus ini dapat ditularkan dari manusia ke manusia dan telah menyebar secara luas di China dan lebih daro 190 negara dan teritori lainya. Pada 12 Maret 2020, WHO mengumumkan COVID-19 sebagai Pandemik. Hingga tanggal 29 maret 2020, terdapat 634.835 kasus dan 33.106 jumlah kematian di seluruh dunia. Sementara di Indonesia sudah di tetapkan 1.528 kasus dengan positif Covid-19 dan 136 kasus kematian.

\section{Kerangka pemikiran}

Kualitas Kualitas Pelayanan

(X1)

Menurut (Tjiptono 2011:347)

Dimensi Kualitas Pelayanan

1. Reliability (Keandalan)

2. Responsiveness (Daya Tanggap)

3. Assurance (Jaminan dan Kepastiap)

4. Emphaty (Kepedulian)

5. Tangible (Wujud Fisik)
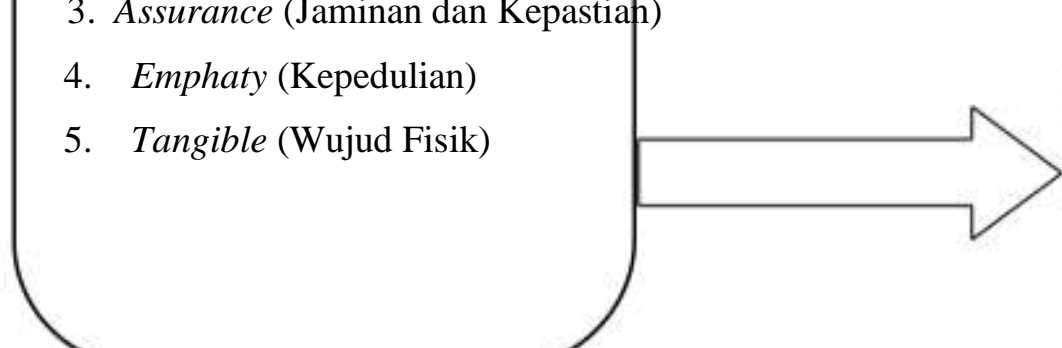

Ketepatan Pengiriman

(X2)

Dinitzen (2010:35)

Dimensi Ketepatan Pengiriman

1. Delivery Time (Waktu Pengiriman )

2. Delivery Flexibility ( Fleksibilitas Waktu)

3. Delivery Accuracy

4. Delivery Stok Service

5. Delivery After-Sales Service

6. Delivery Order Management

7. Delivery Marketing and Communication

8. Delivery E-Information

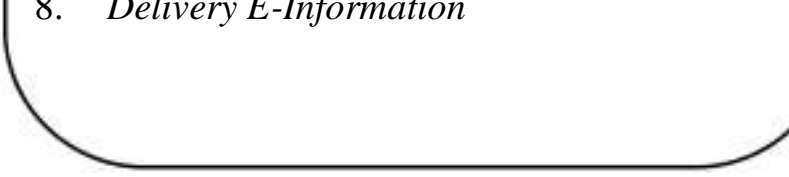

\section{METODE PENELITIAN}




\section{Pendekatan dan jenis penelitian}

Dalam penelitian ini menggunakan pendekatan kuantitatif, Metode Kuantitatif dinamakan metode tradisional, karena metode ini sudah cukup lama digunakan sehingga sudah mentradisi sebagai metode untuk penelitian. Metode ini disebut sebagai metode positivistik karena berlandaskan pada filsafat positivisme. Metode ini sebagai metode ilmiah/scientific karena telah memenuhi kaidah-kaidah ilmiah yaitu konkrit/empiris, obyektif, terukur, rasional, dan sistematis. Metode ini juga disebut metode discovery, karena dengan metode ini dapat ditemukan dan dikembangkan sebagai iptek baru. Metode ini disebut metode kuantitatif karena data penelitian berupa angka-angka dan analisis menggunakan statistik.

\section{Operasionalisasi variabel}

Sesuai dengan judul penelitian ini yaitu pengaruh Kualitas Pelayanan dan Ketepatan Pengiriman terhadap Kepuasan Pelanggan dalam menggunakan jasa pengiriman barang Ninja Express di masa Pandemi Covid-19, maka peneliti mengelompokan variabel independen $\left(\mathrm{X}^{1}\right)$ Kualitas Pelayanan, $\left(\mathrm{X}^{2}\right)$ Ketepatan Pengiriman dan variabel dependen (Y) Kepuasan Pelanggan. Penelitian ini menggunakan variabel dengan indikator sebagai berikut :

\begin{tabular}{|c|c|c|c|}
\hline Variabel & Dimensi & Indikator & No.Instrumen \\
\hline \multirow{8}{*}{$\begin{array}{l}\text { Kualitas Pelayanan } \\
\text { (X1) }\end{array}$} & \multirow{2}{*}{ Keandalan } & Pelayanan & \multirow{2}{*}{1,2} \\
\hline & & Tidak terbelit-belit & \\
\hline & Daya Tanggap & Tanggap Keluhan & 3 \\
\hline & \multirow{2}{*}{ Asuransi } & Keamanan Data & \multirow{2}{*}{4,5} \\
\hline & & Keamanan Barang & \\
\hline & \multirow{2}{*}{ Kepedulian } & Buka Pengiriman & \multirow{2}{*}{6,7} \\
\hline & & Mengirimkan barang & \\
\hline & Wujud Fisik & Kendaraan & 8 \\
\hline \multirow{8}{*}{$\begin{array}{c}\text { Ketepatan } \\
\text { Pengiriman (X2) }\end{array}$} & Delivery Time & Estmasi pengiriman & 1 \\
\hline & Delivery Flexibility & $\begin{array}{c}\text { Melayani di luar jam } \\
\text { kerja }\end{array}$ & 2 \\
\hline & Delivery Accuracy & Mengirimkan barang & 3 \\
\hline & Stock Servise & $\begin{array}{c}\text { Memenuhi stok } \\
\text { pengiriman }\end{array}$ & 4 \\
\hline & After-Sales Service & Informasi tracking & 5 \\
\hline & Order Management & Informasi pemesanan & 6 \\
\hline & $\begin{array}{c}\text { Marketing and } \\
\text { Communication }\end{array}$ & $\begin{array}{l}\text { Memberi informasi } \\
\text { jelas }\end{array}$ & 7 \\
\hline & E-Information & Internet informasi & 8 \\
\hline \multirow{3}{*}{$\begin{array}{c}\text { Kepuasan Pelangan } \\
\text { (Y) }\end{array}$} & \multirow{2}{*}{ Keseseuaian Harapan } & Kesopanan & \multirow{2}{*}{1,2} \\
\hline & & Merasa puas & \\
\hline & Minat Menggunakan lagi & Berminat kembali & 3,4 \\
\hline
\end{tabular}

\section{Teknik pengumpulan data}

Kuesioner merupakan teknik pengumpulan data yang dilakukan dengan cara memberi seperangkat pertanyaan atau pernyataan tertulis kepada responden untuk dijawabnya, Kuesioner dapat berupa pertanyaan atau pernyataan tertutup atau terbuka. Teknik ini dilakukan dengan cara memberikan kuesioner kepada responden yaitu pengguna layanan Ninja Express di Cakung Timur 3.

Skala yang digunakan adalah skala Likert. Skala Likert digunakan untuk mengukur sikap, pendapat, dan persepsi seseorang atau sekelompok orang tentang fenomena. Dengan menggunakan skala Likert setiap 
indikator dirubah menjadi item-item instrument yang di dapat dari pertanyaan atau pernyataan. Setiap pernyataan maupun pertanyaan diukur dengan skala penilaian Likert yang memiliki lima tingkat preferensi jawaban yang masing-masing diberi bobot 1-5.

\section{Populasi san sampel}

Teknik yang digunakan dalam penelitian ini adalah dengan teknik nonprobability sampling. Metode yang digunakan adalah accidental sampling. Sampel dalam penelitian ini didapatkan dengan melakukan pertanyaan-pertanyaan menggunakan kuesioner kepada responden pengguna jasa kurir online di gerai Ninja Express Cakung Timur 3. Untuk menentukan sampel menggunakan rumus slovin sebagai berikut :

$$
\begin{aligned}
& \text { nimana : } \\
& \mathrm{n} \quad=\frac{\mathrm{N}}{1+\mathrm{N}(\mathrm{e})} 2 \\
& \mathrm{~N}=\text { Ukuran Populasi } \\
& \text { e= Batas toleransi kesalahan (eror tolerance) }
\end{aligned}
$$

Dari jumlah populasi tersebut dengan tingkat kelonggaran ketidak telitian 10\% maka dengan menggunakan rumus diatas memperoleh sampel sebesar :

$$
\begin{array}{ll} 
& 15 \\
\mathrm{n} \quad=150 & \frac{150(0 .}{1+150}
\end{array} \quad=\quad=60 \text { orang }
$$

Dengan demikian, maka jumlah sampel yang digunakan oleh peneliti berjumlah 60 responden menggunakan kuesioner.

\section{TEKNIK ANALISIS DATA}

a. Uji Validitas dan Reabilitas

1). Uji Validitas

Menurut Imam Ghozali (2013) Uji Validitas digunakan untuk mengukur sah atau valid tidaknya suatu kuesioner. Suatu kuesioner dikatakan valid jika pertanyaan pada kuesioner mampu untuk mengungkapkan sesuatu yang akan diukur oleh kuesioner tersebut.

Tingkat validitas dapat diukur dengan membandingkan nilai $r$ hitung (correlation item total correlation) dengan $\mathrm{r}$ tabel dengan ketentuan degree of freedom $(\mathrm{df})=\mathrm{n}-2$, dimana $\mathrm{n}$ adalah jumlah sampel dengan $\alpha=$ $5 \%$, kriteria untuk penilaian uji validitas sebagai berikut :

a). Apabila $r$ hitung $>\mathrm{r}$ tabel, maka item kuesioner tersebut valid.

b). Apabila $r$ hitung $<\mathrm{r}$ tabel, maka dapat dikatakan item kuesioner tidak valid.

2). Uji Reabilitas

Uji Reliabilitas adalah indeks yang menunjukkan sejauh mana alat ukur dapat dpercaya atau diandalkan. Hal ini berati menunjukan sejauh mana alat pengukur dikatakan konsisten, jika dilakukan pengukuran dua kali atau lebih terhadap gejala yang sama. Artinya data yang digunakan reliabilitas adalah alat ukur yang digunakan bisa menunjukan hasil yang sama walaupun digunakan berkali-kali oleh peneliti yang berbeda.Uji Reabilitas menggunakan metode Cornbach Alpha di program SPSS dengan kriteria pengujian sebagai berikut :

a). Jika nilai Alpha $>0.6$ berarti pernyataan reliable

b). Jika nilai Alpha $<0.6$ berarti pernyataan tidak reliable

b. Uji Asumsi Klasik 


\section{1). Uji normalitas}

Uji Normalitas digunakan untuk mengetahui apakah populasi data berdistribusi normal atau tidak. Suatu penelitian data yang diperlukan harus bervariabel normal, bila data dari setiap variabel tidak normal maka tidak bisa menggunakan statistik parametrik. Ditribusi dari rata-rata sampel hasil dari observasi akan mendekati normal bila jumlah individu sampel semakin besar. Metode normalitas dalam penelitian ini dilakukan dengan mengunakan teknik statistik kolmogrow-smirnov atau dikenal dengan uji K-S dan data dinyatakan berdistribusi normal jika data mengikuti bentuk distribusi normal dan dilihat dari nilai-nilai risidual yang dihasilkan diatas nilai signifikasi yang ditetapkan yaitu sebesar 0,05 atau 5\% maka variabel distribusi normal.

\section{2). Multikolinieritas}

Menurut (Ghozali, 2013:105) uji ini bertujuan untuk menguji apakah model regresi ditemukan adanya korelasi antara variabel bebas (independen). Model regresi yang baik seharusnya tidak terjadi korelasi di antar variabel independen. Untuk medeteksi ada tidaknya multikolinearitas dalam model regresi dapat dilihat dari Tolerance Value atau Variance Inflation Factor (VIF).

a). Jika nilai Tolerance $>0,10$ persen dan nilai VIF $<10$, maka dapat disimpulkan bahwa tidak ada multikolinearitas antar variabel independen dalam model regresi.

b). Jika nilai Tolerance $<0,10$ persen dan nilai VIF $>10$ maka dapat disimpulkan bahwa ada multikolinearitas antar variabel independen dalam model regresi.

\section{3). Uji Heteroskedastisitas}

Deteksi heteroskedastisitas dapat dilakukan dengan metode scatter plot dengan memplotkan nilai ZPRED (nilai prediksi) dengan SRESID (nilai residunya). Model yang baik didapatkan jika tidak terdapat pola tertentu pada grafik, seperti mengumpul ditengah, menyempit kemudian melebar atau sebaliknya melebar kemudian menyempit.

\section{c. Uji Hipotesis}

\section{1). Uji Koefisien Determinasi}

Koefisien Determinasi menunjukkan suatu proporsi dari varian yang dapat diterangi oleh persamaan regresi terhadap varian total. Nilai koefisien korelasi lebih bebas menjelaskan variabel terikat dengan baik atau kuat (signifikan), sama dengan 0,5 atau kurang dari 0,5 relatif kurang baik. Rumus yang digunakan sebagai berikut :

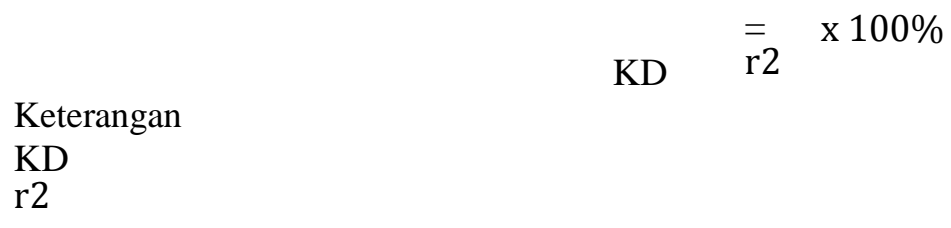

: Koefisien Determinasi

: Koefisien Korelasi

: Koefisien Determinasi

: Koefisien Korelasi

2). Uji T (Parsial)

Uji statistik t pada dasarnya mewujudkan seberapa jauh pengaruh satu variabel independen secara individual dalam menerangkan variasi variabel dependen. Pengujian hipotesis dengan uji $t$ adalah pengujian hipotesis secara parsial, yang bertujuan untuk mengetahui seberapa besar pengaruh variabel independen secara masing-masing atau parsial terhadap variabel dependen.

\section{3). Uji F (Simultan)}

Uji F pada dasarnya menunjukkan apakah semua variabel independen atau bebas yang dimasukan dalam model mempunyai pengaruh secara bersama-sama terhadap variabel dependen/ terikat.

\section{d. Uji Regresi Linier Berganda}

Pengujian terhadap hipotesis dalam penelitian ini menggunakan analisis regresi berganda. Analisis regresi berganda ini digunakan untuk mengetahui pengaruh kualitas pelayanan dan ketepatan pengiriman terhadap kepuasan pelanggan. Untuk mencari, digunakan rumus sebagai berikut : 


$$
\mathrm{Y}=\mathrm{a}+\mathrm{b} 1 \mathrm{X} 1+\mathrm{b} 2 \mathrm{X} 2+\mathrm{e}
$$

Keterangan :

$\begin{array}{ll}\text { a } & : \text { Konstanta } \\ \text { b1 } & : \text { Koefisien regresi kualitas pelayanan } \\ \text { b2 } & : \text { Koefisien regresi ketepatan pengiriman } \\ \text { X1 } & \text { kualitas pelayanan } \\ \text { X2 } & : \text { ketepatan pengiriman } \\ \text { Y } & : \text { Kepuasan pelanggan } \\ \text { e } & : \text { Eror }\end{array}$

\section{TEMPAT PENELITIAN}

Lokasi penelitian merupakan bagian yang penting untuk melakukan penelitian dan juga mendapatkan data yang akurat. Lokasi penelitian yang dilakukan oleh peneliti adalah gerai Ninja Express Cakung Timur 3, Jakarta Timur.

\section{HASIL DAN PEMBAHASAN}

Hasil Rekapitulasi Variabel Kualitas Pelayanan

\begin{tabular}{|c|l|c|c|}
\hline No & \multicolumn{1}{|c|}{ Indikator } & Nilai & Interpretasi \\
\hline 1 & $\begin{array}{l}\text { Pihak Ninja Express cepat dalam } \\
\text { melayani pelanggan }\end{array}$ & 4,16 & Baik \\
\hline 2 & $\begin{array}{l}\text { Prosedur pelayanan Ninja Express tidak } \\
\text { terbelit - belit }\end{array}$ & 4,3 & Sangat Baik \\
\hline 3 & $\begin{array}{l}\text { Pihak Ninja Express tanggap dalam } \\
\text { keluhan pelanggan }\end{array}$ & 4,18 & Baik \\
\hline 4 & $\begin{array}{l}\text { Pihak Ninja Express menjamin } \\
\text { keamanan barang }\end{array}$ & 4,18 & Baik \\
\hline 5 & $\begin{array}{l}\text { Pihak Ninja Express menjamin } \\
\text { kemanan data pelanggan }\end{array}$ & 4,03 & Baik \\
\hline 6 & $\begin{array}{l}\text { Pihak Ninja Express buka dalam Office } \\
\text { Hour }\end{array}$ & 4,18 & Baik \\
\hline 7 & $\begin{array}{l}\text { Pihak Ninja Express bersedia } \\
\text { mengantarkan barang }\end{array}$ & 4,08 & Baik \\
\hline 8 & $\begin{array}{l}\text { Kendaraan tersedia untuk } \\
\text { mengantarkan barang }\end{array}$ & 4,31 & Sangat Baik \\
\hline & Jumlah & 33,42 & Baik \\
\hline
\end{tabular}

Dalam skala Interval yang diperoleh di Variabel Kualitas Pelayanan sebesar 4,17 dengan kriteria Baik.

Hasil Rekapitulasi Variabel Ketepatan Pengiriman

\begin{tabular}{|c|l|c|c|}
\hline No & \multicolumn{1}{|c|}{ Indikator } & Nilai & Interpretasi \\
\hline 1 & $\begin{array}{l}\text { Pengiriman barang sesuai } \\
\text { dengan estimasi }\end{array}$ & 4,38 & Sangat Baik \\
\hline 2 & $\begin{array}{l}\text { Pihak Ninja Express tetap } \\
\text { melayani diluar Jam Kerja }\end{array}$ & 4,28 & Sangat Baik \\
\hline 3 & $\begin{array}{l}\text { Pengiriman barang sesuai } \\
\text { kepada penerima }\end{array}$ & 4,3 & Sangat Baik \\
\hline 4 & $\begin{array}{l}\text { Pihak Ninja Express dapat } \\
\text { memenuhi stock pengiriman }\end{array}$ & 4,28 & Sangat Baik \\
\hline
\end{tabular}




\begin{tabular}{|c|l|c|c|}
\hline 5 & Penyediaan informasi Tracking & 4,25 & Sangat Baik \\
\hline 6 & $\begin{array}{l}\text { Menyediakan informasi } \\
\text { mengenai pesanan pelanggan }\end{array}$ & 4,4 & Sangat Baik \\
\hline 7 & $\begin{array}{l}\text { Pihak Ninja Express } \\
\text { memberikan informasi ke } \\
\text { pelanggan }\end{array}$ & 4,06 & Baik \\
\hline 8 & $\begin{array}{l}\text { Informasi yang Update dan } \\
\text { Realtime melalui Internet }\end{array}$ & 4,25 & Sangat Baik \\
\hline \multicolumn{2}{r|}{ Jumlah } & 34,2 & Sangat Baik \\
\hline
\end{tabular}

Dalam skala Interval yang diperoleh di Variabel Ketepatan Pengiriman sebesar 4,27 dengan kriteria Sangat Baik.

Hasil Rekapitulasi Variabel Kepuasan Pelanggan

\begin{tabular}{|c|l|c|c|}
\hline No & \multicolumn{1}{|c|}{ Indikator } & Nilai & Interpretasi \\
\hline 1 & $\begin{array}{l}\text { Anda merasa puas atas pelayanan } \\
\text { Ninja Express }\end{array}$ & 4,21 & Sangat Baik \\
\hline 2 & $\begin{array}{l}\text { Pihak Ninja Express berperilaku } \\
\text { sopan terhadap anda }\end{array}$ & 4,26 & Sangat Baik \\
\hline 3 & $\begin{array}{l}\text { Apa anda berminat untuk } \\
\text { menggunakan layanan Ninja Express } \\
\text { kembali }\end{array}$ & 4,06 & Baik \\
\hline 4 & $\begin{array}{l}\text { Apa kesopanan Ninja Express } \\
\text { membuat anda melakukan pesanan } \\
\text { kembali }\end{array}$ & 4,21 & Sangat Baik \\
\hline 5 & $\begin{array}{l}\text { Apakah anda bersedia } \\
\text { merekomendasikan jasa Ninja } \\
\text { Express tesebut ke temen }\end{array}$ & 4,03 & Baik \\
\hline 6 & $\begin{array}{l}\text { Apakah anda bersedia } \\
\text { merekomendasikan jasa Ninja } \\
\text { Express tesebut ke keluarga }\end{array}$ & 4,13 & Baik \\
\hline \multicolumn{1}{|c|}{ Jumlah } & 24,9 & Baik \\
\hline
\end{tabular}

Dalam skala Interval yang diperoleh di Variabel Kepuasan Pelanggan sebesar 4,15 dengan kriteria Baik. a. Uji Validitas dan Reabilitas

1). Uji Validitas

\begin{tabular}{|c|c|c|c|}
\hline Variabel & R hitung & R tabel & Keterangan \\
\hline $\mathrm{X} 1.1$ & 0,733 & 0,254 & Valid \\
\hline $\mathrm{X} 1.2$ & 0,803 & 0,254 & Valid \\
\hline $\mathrm{X} 1.3$ & 0,677 & 0,254 & Valid \\
\hline $\mathrm{X} 1.4$ & 0,735 & 0,254 & Valid \\
\hline $\mathrm{X} 1.5$ & 0,506 & 0,254 & Valid \\
\hline $\mathrm{X} 1.6$ & 0,666 & 0,254 & Valid \\
\hline $\mathrm{X} 1.7$ & 0,672 & 0,254 & Valid \\
\hline $\mathrm{X} 1.8$ & 0,843 & 0,254 & Valid \\
\hline
\end{tabular}

Pada tabel di atas menunjukan bahwa Variabel Kualitas Pelayanan (X1) memiliki nilai R hitung di atas nilai $R$ tabel yang besaranya 0,254 atau $R$ hitung $>R$ tabel maka dengan data yang di peroleh pertanyaan untuk Variabel X1 dinyatakan Valid. 


\begin{tabular}{|c|c|c|c|}
\hline Variabel & R hitung & R tabel & Keterangan \\
\hline X2.1 & 0,607 & 0,254 & Valid \\
\hline X2.2 & 0,715 & 0,254 & Valid \\
\hline X2.3 & 0,760 & 0,254 & Valid \\
\hline X2.4 & 0,669 & 0,254 & Valid \\
\hline X2.5 & 0,673 & 0,254 & Valid \\
\hline X2.6 & 0,696 & 0,254 & Valid \\
\hline X2.7 & 0,611 & 0,254 & Valid \\
\hline X2.8 & 0,627 & 0,254 & Valid \\
\hline
\end{tabular}

Dari tabel di atas menunjukan bahwa Variabel Ketepatan Pengiriman (X2) memiliki nilai R hitung di atas nilai $\mathrm{R}$ tabel yang besaranya 0,254 atau $\mathrm{R}$ hitung $>\mathrm{R}$ tabel maka dengan data yang di peroleh pertanyaan untuk Variabel X2 dinyatakan Valid.

\begin{tabular}{|c|c|c|c|}
\hline Variabel & R hitung & R tabel & Keterangan \\
\hline Y1 & 0,592 & 0,254 & Valid \\
\hline Y2 & 0,741 & 0,254 & Valid \\
\hline Y3 & 0,596 & 0,254 & Valid \\
\hline Y4 & 0,753 & 0,254 & Valid \\
\hline Y5 & 0,688 & 0,254 & Valid \\
\hline Y6 & 0,679 & 0,254 & Valid \\
\hline
\end{tabular}

Dari tabel di atas menunjukan bahwa Variabel Kepuasan Pelanggan (Y) memiliki nilai R hitung di atas nilai $R$ tabel yang besaranya 0,254 atau $R$ hitung > $R$ tabel maka dengan data yang di peroleh pertanyaan untuk Variabel Y dinyatakan Valid.

2). Uji Reabilitas

\begin{tabular}{|c|c|c|c|c|}
\hline Variabel & $\begin{array}{c}\text { Hasil } \\
\text { Cronbach } \\
\text { Alpha }\end{array}$ & N of Items & Cronbach Alpha & Keterangan \\
\hline $\mathrm{X} 1$ & 0,844 & 8 & $0,6 \mathrm{OO}$ & reliable \\
\hline $\mathrm{X} 2$ & 0,815 & 8 & $0,6 \mathrm{OO}$ & reliable \\
\hline $\mathrm{Y}$ & 0,753 & 6 & $0,6 \mathrm{OO}$ & reliable \\
\hline
\end{tabular}

Dari tabel di atas menujukan bahwa nilai Cornbach Alpha dari masing-masing Variabel melebihi dari 0,600 dengan ini dapat disimpulkan bahwa Variabel dalam penelitian ini dapat di terima dengan baik.

b. Uji Asumsi Klasik

1). Uji Normalitas

\begin{tabular}{|c|c|c|c|}
\hline \multicolumn{4}{|c|}{ One-Sample Kolmogorov-Smirnov Test } \\
\hline & & & $\begin{array}{c}\text { Unstandardize } \\
\text { d Residual }\end{array}$ \\
\hline \multicolumn{2}{|l|}{$\mathrm{N}$} & & 60 \\
\hline \multirow[t]{2}{*}{ Normal Parameters ${ }^{\mathrm{a}, \mathrm{v}}$} & Mean & &, 0000000 \\
\hline & Std. Deviation & & 1,82379140 \\
\hline \multirow{3}{*}{$\begin{array}{l}\text { Most Extreme } \\
\text { Differences }\end{array}$} & Absolute & &, 152 \\
\hline & Positive & &, 152 \\
\hline & Negative & &,- 099 \\
\hline \multicolumn{2}{|l|}{ Test Statistic } & &, 152 \\
\hline \multicolumn{2}{|l|}{ Asymp. Sig. (2-tailed) } & &, $001^{\mathrm{C}}$ \\
\hline \multirow{3}{*}{$\begin{array}{l}\text { Monte Carlo Sig. (2- } \\
\text { tailed) }\end{array}$} & Sig. & & $109^{\mathrm{a}}$ \\
\hline & \multirow{2}{*}{$\begin{array}{l}\text { 99\% Confidence } \\
\text { Interval }\end{array}$} & Lower Bound &, 101 \\
\hline & & Upper Bound & 117 \\
\hline
\end{tabular}



b. Calculated from data.
c. Lilliefors Significance Correction.
d. Based on 10000 sampled tables with starting seed 2000000.

Dengan melihat data di atas Nilai Sig. sebesar 0,109>0,05 maka di dapat bahwa Variabel yang di gunakan berdistribusi Normal.

2). Uji Multikoliieritas

\begin{tabular}{|c|c|c|c|c|c|c|c|c|}
\hline \multicolumn{9}{|c|}{ Coefficients $^{\mathrm{a}}$} \\
\hline & & \multicolumn{2}{|c|}{$\begin{array}{c}\text { Unstandardized } \\
\text { Coefficients }\end{array}$} & \multirow{2}{*}{\begin{tabular}{|c|}
$\begin{array}{c}\text { Standardiz } \\
\text { ed } \\
\text { Coefficien } \\
\text { ts }\end{array}$ \\
Beta \\
\end{tabular}} & \multirow[b]{2}{*}{$\mathrm{t}$} & \multirow[b]{2}{*}{ Sig. } & \multicolumn{2}{|c|}{$\begin{array}{l}\text { Collinearity } \\
\text { Statistics }\end{array}$} \\
\hline \multicolumn{2}{|c|}{ Model } & B & Std. Error & & & & $\begin{array}{c}\text { Toleran } \\
\text { ce }\end{array}$ & VIF \\
\hline \multirow[t]{4}{*}{1} & (Constant) & 8,376 & 2,684 & & 3,121 & ,003 & & \\
\hline & \begin{tabular}{|l|} 
Kualitas \\
Pelayanan \\
\end{tabular} & ,390 & ,079 & $\overline{5}, 570$ & 4,941 & ,000 & ,749 & 1,334 \\
\hline & $\begin{array}{l}\text { Ketepatan } \\
\text { Pengiriman }\end{array}$ & ,103 & ,079 &, 150 & 1,301 & ,199 & ,749 & 1,334 \\
\hline & a. Dependent & : Kepua & in Pelang & & & & & \\
\hline
\end{tabular}

Dari tabel di atas terlihat bahwa Nilai Tolerance dari variable Kualitas Pelayanan dan Ketepatan Pengiriman Sebesar 0,749 > 0,10 dan Nilai VIF dari kedua variabel sebesar 1,334<10, Maka denga data di atas terbebas dari Multikolinieritas.

3). Uji Heteroskedastisitas

\section{Scatterplot}

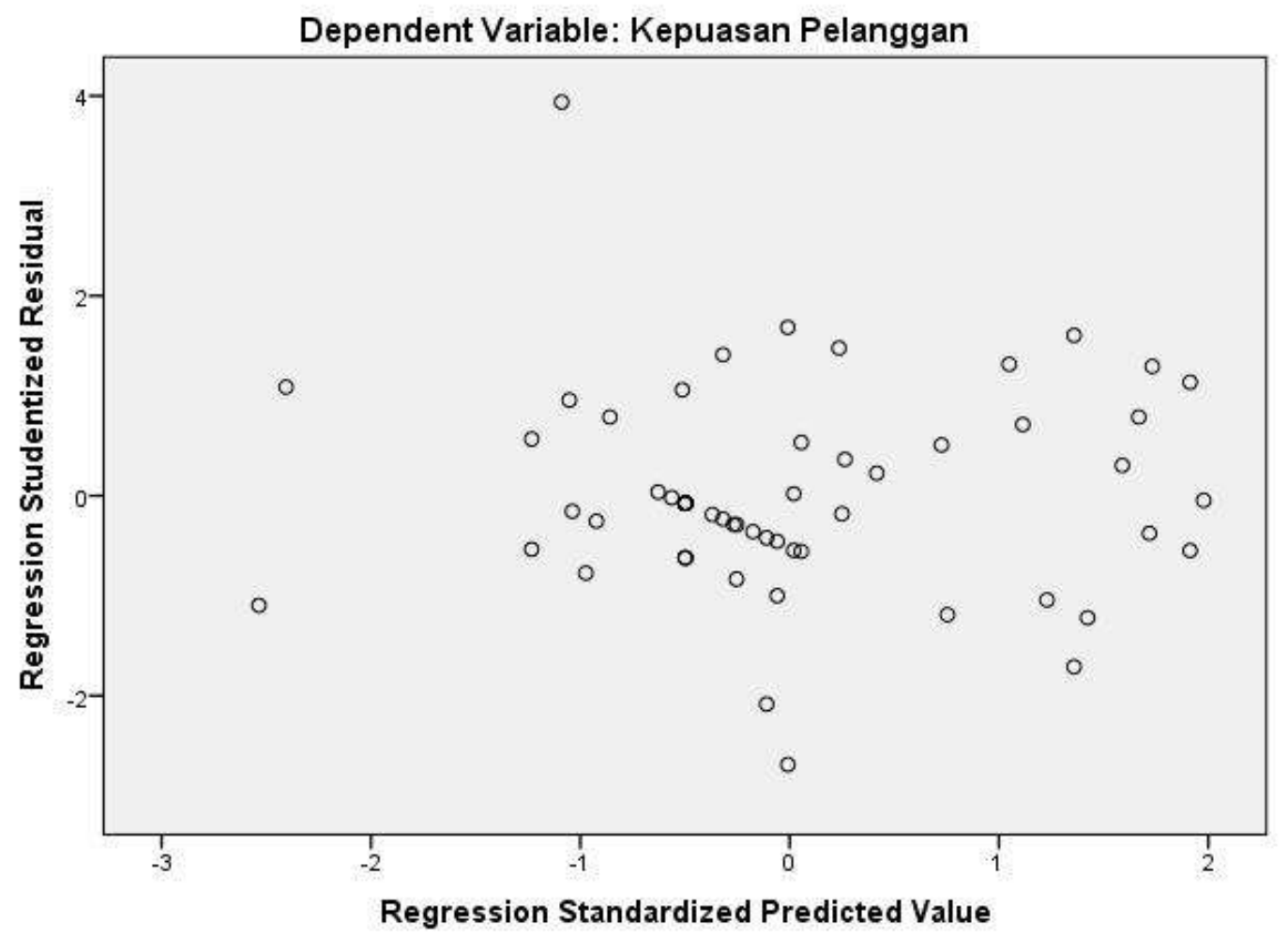

Dari data di atas dapat disimpulakan bahwa tidak terjadi masalah heteroskedastisitas terlihat dari titiktitik yang menyebar di atas, dibawah, dikanan, dikiri dari titik 0. Jadi dapat disimpulkan tidak terjadi heteroskedastisitas. 


\section{c. Uji Hipotesis}

1). Uji Koefisien Determinasi

\begin{tabular}{|l|c|r|c|r|}
\hline \multicolumn{5}{|c|}{ Model Summary } \\
\hline Model & $\mathrm{R}$ & $\mathrm{R}$ Square & $\begin{array}{c}\text { Adjusted R } \\
\text { Square }\end{array}$ & $\begin{array}{r}\text { Std. Error of } \\
\text { the Estimate }\end{array}$ \\
\hline 1 & \multicolumn{6}{|c|}{$658^{\mathrm{a}}$} &, 432 &, 412 & 1,856 \\
\hline \multicolumn{7}{|c|}{ a. Predictors: (Constant), Total_X2, Total_X1 } \\
\hline
\end{tabular}

Berdasarkan tabel di atas, menunjukan bahwa Adjusted R Square sebesar 0,412 atau 41,2\%. Ini menunjukan bahwa Kualitas Pelayanan dan Ketepatan Pengiriman memiliki pengaruk terhadap Kepuasan pelanggan sebesar $41,2 \%$ sedangkan 58,8\% dipengaruhi oleh variabel lain yang tidak di teliti dalam penelitian ini.

\section{2). Uji T}

\begin{tabular}{|c|c|c|c|c|c|c|}
\hline & \multicolumn{6}{|c|}{ Coefficients $^{\mathrm{a}}$} \\
\hline & & \multicolumn{2}{|c|}{ Unstandardized } & Standardized & & \\
\hline & & \multicolumn{2}{|c|}{ Coefficients } & Coefficients & & \\
\hline Model & & $\mathrm{B}$ & Std. Error & Beta & $\mathrm{T}$ & Sig. \\
\hline \multirow[t]{4}{*}{1} & (Constant) & 8,376 & 2,684 & & 3,121 & ,003 \\
\hline & Kualitas Pelayanan & ,390 & ,079 &, 570 & 4,941 &, 000 \\
\hline & Ketepatan Pengiriman & ,103 &, 079 &, 150 & 1,301 & , 199 \\
\hline & \multicolumn{6}{|c|}{ a. Dependent Variable: Kepuasan Pelanggan } \\
\hline
\end{tabular}

Dan untuk variabel Ketepatan Pengiriman (X2) dengan Nilai T hitung 1,301 < T tabel 2,002 dan juga Nilai Signifikansi 0,199 > 0,05 dengan ini dapat disimpulkan bahwa (X2) tidak mempunyai pengaruh signifikan terhadap variabel Kepuasan Pelanggan (Y).

Dan untuk variabel Ketepatan Pengiriman (X2) dengan Nilai T hitung 1,301 $<\mathrm{T}$ tabel 2,002 dan juga Nilai Signifikansi 0,199>0,05 dengan ini dapat disimpulkan bahwa (X2) tidak mempunyai pengaruh signifikan terhadap variabel Kepuasan Pelanggan (Y).

3). Uji F

\begin{tabular}{|c|c|c|c|c|c|c|}
\hline & \multicolumn{6}{|c|}{ ANOVAa } \\
\hline & & Sum of & & & & \\
\hline Model & & Squares & $\mathrm{df}$ & Mean Square & $\mathrm{F}$ & Sig. \\
\hline \multirow{5}{*}{1} & Regression & 149,487 & 2 & 74,743 & 21,709 &, $000^{\mathrm{b}}$ \\
\hline & Residual & 196,247 & 57 & 3,443 & & \\
\hline & Total & 345,733 & 59 & & & \\
\hline & \multicolumn{6}{|c|}{ a. Dependent Variable: Total_Y } \\
\hline & \multicolumn{6}{|c|}{ b. Predictors: (Constant), Total_X2, Total_X1 } \\
\hline
\end{tabular}

Dari tabel di atas dapat disimpulkan bahwa nilai signifikan 0,000 $<0,05$ dan juga Nilai F hitung 21,709 $>\mathrm{F}$ tabel 3.16 dengan ini maka dapat disimpulkan bahwa Kualitas Pelayanan (X1) dan Ketepatan Pengiriman (X2) secara bersama-sama mempunyai pengaruh terhadap Kepuasan Pelanggan (Y).

d. Uji Regresi Linier Berganda 


\begin{tabular}{|c|c|c|c|c|c|c|}
\hline \multicolumn{7}{|c|}{ Coefficients $^{a}$} \\
\hline \multirow{3}{*}{\multicolumn{2}{|c|}{ Model }} & \multirow{2}{*}{\multicolumn{2}{|c|}{$\begin{array}{c}\text { Unstandardized } \\
\text { Coefficients }\end{array}$}} & \multirow{3}{*}{$\begin{array}{c}\text { Standardized } \\
\text { Coefficients } \\
\text { Beta } \\
\end{array}$} & \multirow[b]{3}{*}{$\mathrm{t}$} & \multirow[b]{3}{*}{ Sig. } \\
\hline & & & & & & \\
\hline & & $\mathrm{B}$ & Std. Error & & & \\
\hline \multirow{4}{*}{1} & (Constant) & 8,376 & 2,684 & & 3,121 &, 003 \\
\hline & Kualitas Pelayanan & ,390 & ,079 & ,570 & 4,941 & ,000 \\
\hline & Ketepatan Pengiriman &, 103 & 079 &, 150 & 1,301 &, 199 \\
\hline & \multicolumn{6}{|c|}{ a. Dependent Variable: Kepuasan Pelanggan } \\
\hline
\end{tabular}

1). Hasil koefisien regresi linier berganda memperlihatkan nilai kostanta sebesar 8,376 secara sistematis menyatakan bahwa jika nilai variabel bebas (X1) dan (X2) sama dengan 0 maka nilai Y=8,376. Dalam kata lain bahwa Kepuasan Pelanggan tanpa Kualitas Pelayanan dan Ketepatan Pengiriman adalah 8,376.

2). Koefisien regresi variabel Kualitas Pelayanan (X1) sebesar 0,390 artinya bahwa tiap peningkatan Kualitas Pelayanan sebesar satu satuan, maka Kepuasan Pelanggan (Y) bertambah sebesar 0,390 satuan atau Kualitas Pelayanan mampu menjelaskan Kepuasan Pelanggan.

3). Koefisien regresi variabel Ketepatan Pengiriman (X2) sebesar 0,103 artinya bahwa tiap peningkatan Ketepatan Pengiriman sebesar satu satuan, maka Kepuasan Pelanggan (Y) bertambah sebesar 0,103 satuan atau Ketepatan Pengiriman mampu menjelaskan Kepuasan Pelanggan.

\section{PEMBAHASAN}

Berdasarkan data yang telah peneliti dapatkan dalam penelitian ini, maka peneliti selanjutnya melakukan besar pengaruh Kualitas Pelayanan dan Ketepatan Pengiriman terhadap Kepuasan pelanggan.

Berdasarakan hasil dari data Rekapitulasi Kualitas Pelayanan pada variabel (X1) didapatkan hasil ratarata sebesar 4,17 dengan nilai baik. Akan tetapi masih ada 3 indikator yang masih di bawah nilai rata-rata sebagai berikut :

a. Pihak Ninja Express cepat dalam melayani pelanggan dengan nilai 4,16.

b. Pihak Ninja Express menjamin kemanan data pelanggan dengan nilai 4,03.

c. Pihak Ninja Express bersedia mengantarkan barang dengan nilai 4,08.

Hal ini menunjukan bahwa pihak Ninja Express harus meningkatkan Kualitas Pelayanan agar indikator yang berada dibawah rata-rata ini bisa meningkat.

Selanjutnya adalah hasil Rekapitulasi Ketepatan Pengiriman pada variabel (X2) didapat nilai rata-rata sebesar 4,27 dengan nilai sangat baik. Akan tetapi masih ada 3 indikator yang berada dibawah nilai rata-rata sebagai berikut :

a. Penyediaan informasi Tracking dengan nilai 4,25.

b. Pihak Ninja Express memberikan informasi ke pelanggan dengan nilai 4,06.

c. Informasi yang Update dan Realtime melalui Internet dengan nilai 4,25.

Selanjutnya adalah hasil Rekapitulasi Kepuasan Pelanggan pada variabel (Y) didapat nilai rata-rata sebesar 4,15 dengan nilai baik. Akan tetapi masih ada 3 indikator yang berada dibawah nilai rata-rata sebagai berikut :

a. Apa anda berminat untuk menggunakan layanan Ninja Express kembali dengan nilai 4,06.

b. Apakah anda bersedia merekomendasikan jasa Ninja Express tesebut ke temen dengan nilai 4,03.

c. Apakah anda bersedia merekomendasikan jasa Ninja Express tesebut ke keluarga dengan nilai 4,13.

\section{KESIMPULAN}

Berdasarkan hasil analisis dari data yang telah di peroleh oleh peneliti dapat mengambil kesimpulan bahwa variabel Kualitas Pelayanan (X1) dan variabel Ketepatan Pengiriman (X2) berpengaruh terdahap Kepuasan Pelanggan (Y) dengan nilai sebesar 41,2\% sedangkan 58,8\% dipengaruhi oleh faktor atau variabel lain yang tidak diteliti oleh penelitian ini.

Dan dapat disimpulkan bahwa juga nilai signifikan 0,000 < 0,05 dan juga Nilai F hitung 21,709F tabel 3.16 dengan ini maka dapat disimpulkan bahwa Kualitas Pelayanan (X1) dan Ketepatan Pengiriman (X2) secara bersama-sama mempunyai pengaruh terhadap Kepuasan Pelanggan (Y). 


\section{REFERENSI}

Andriansyah. (2015). Manajemen Transportasi Dalam Kajian dan Teori. Fakultas Ilmu Sosial dan Ilmu Politik Universitas Prof.Dr. Moestopo Beragama

Fandy, Tjiptono. 2011. Service Management Mewujudkan Layanan Prima. Edisi 2. Yogyakarta: Andi Fandy, Tjiptono. Pemasaran Jasa (Prinsip, Penerapan, Penelitian.), Yogyakarta : Andi ,2014). Ghozali, Imam. 2009. Aplikasi Analisis Multivariaget dengan Program SPSS. Semarang :UNDIP. Hurriyati, R. (2014). Bauran Pemasaran dan Loyalitas Konsumen. Bandung : Alfabeta. Irawan, Handi. 2009. 10 Prinsip Kepuasan Pelanggan, Jakarta : Elek Media Komputindo

Lewis \& Boom (2012). Service, Quality \& Satisfaction. Edisi ke 3. Fandy Tjiptono\& Gregorius Chandra, Yogyakarta: Penerbit Andi.

Lovelock, C., Wirtz, J., \& Jacky Mussry. (2011). Pemasaran Jasa. edisi 7. Erlangga: Jakarta.

Ratnasari T. Ririn., Mastuti H Aksa. (2011). Manajemen Pemasaran Jasa. Penerbit: Ghalia Indonesia.

Sugiyono. 2010. Metode Penelitian Pendidikan Pendekatan Kuantitatif, kualitatif, dan R\&D, Bandung: Alfabeta

Sugiyono. 2019. Metode penelitian Kuantitatif Kualitatif dan $R \& D$. Edisi kedua. Bandung: Alfabeta

Umar, Husein. Studi Kelayakan Bisnis Edisi Kelima. Jakarta: Gramedia PustakaUtama. 2012. 